\title{
Culture media to detect and criteria to evaluate and report the activity of extracellular enzymes produced by phytopathogenic fungi
}

\author{
Meios de cultura para detectar e critérios para avaliar e divulgar \\ atividade de enzimas extracelulares produzidas por fungos fitopatogênicos
}

\author{
Ana Beatriz Monteiro Ferreira' (D), Ivan Herman Fischer ${ }^{2}$ (D), \\ Luís Garrigós Leite ${ }^{1}$ (D), Carlos Roberto Padovani ${ }^{3}$ (D), César Júnior Bueno ${ }^{1 *}$ (D)
}

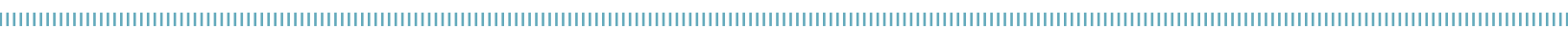

\begin{abstract}
Extracellular enzymes are involved in the fungal pathogenesis in plants. Currently, culture media, data analyses, and data report related to extracellular enzymes produced in vitro conditions are different and therefore, lack standardization. This work aimed to compare the culture media cited on the literature (normal) with the potato-dextrose-agar (PDA) medium combined with a specific compound to produce extracellular enzymes through three soilborne phytopathogenic fungi (F. solani f. sp. passiflorae, S. rolfsii, and $R$. solani AG-4 $\mathrm{HGI}$, as well as to analyze and report enzyme data based on five different criteria. The assay was randomized, with three factors (culture media, isolates, and enzymes) and six repetitions. The studied enzymes were amylase (AM), carboxymethylcellulase (CMCase), lipase (LP), laccase (LC), catalase (CT), and gelatinase (GT). The normal media detected more enzymes and was more precise compared to the PDA medium plus specific compound. The criteria that calculated the area of the circular crown of AM, CMCase, LP, and LC and measured the intensity ( $0=$ absence, up to $4=$ intense) of CT and GT adopting note scale were the best to evaluate and report the results of the enzymes. We suggest the normal media culture to study enzyme production, as well as the criteria mentioned to assess and report the data related to enzyme activities.
\end{abstract}

KEYWORDS: enzymes; soilborne phytopathogenic fungi; methodology.
RESUMO: As enzimas extracelulares estão envolvidas na patogênese de fungos em plantas. Atualmente, não há uma padronização de meios de cultura, formas de analisar e divulgar os dados de enzimas extracelulares produzidas em condições in vitro. Assim, o presente trabalho objetivou comparar os meios de cultura específicos relatados na literatura (normal) com o meio de batata-dextrose-ágar mais adiçâo do substrato específico para produção de enzimas extracelulares por três diferentes fungos fitopatogênicos habitantes de solo (Fusarium solani f. sp. passiflorae, Sclerotium rolfsii e Rhizoctonia solani AG-4 HGI), bem como avaliar os dados das enzimas por cinco critérios diferentes. $\mathrm{O}$ delineamento experimental adotado foi o inteiramente ao acaso, em esquema de três fatores (meios, isolados e enzimas), com seis repetições. As enzimas investigadas foram amilase, carboximetilcelulase, lipase, lacase, catalase e gelatinase. Os meios normais detectaram mais enzimas, e essa detecção foi mais precisa em comparação com os meios de batata-dextrose-ágar mais o substrato específico. Os critérios que calcularam a área da coroa circular para as enzimas amilase, carboximetilcelulase, lipase e lacase e adotaram a escala de notas para medir a intensidade ( $0=$ ausência até $4=$ intensa) de catalase e gelatinase foram os melhores para avaliar e divulgar os resultados das enzimas. Assim, sugere-se padronizar os meios normais para estudos de produção de enzimas, bem como os critérios citados para avaliar e divulgar os dados das atividades das referidas enzimas.

PALAVRAS-CHAVE: enzimas; fungos fitopatogênicos habitantes de solo; metodologia. 


\section{INTRODUCTION}

Enzymes are large protein molecules which catalyze all interrelated reactions in a living cell. They speed up biochemical reactions at a temperature compatible with the normal functioning of the cell. The structure of the enzymes determines its specificity. The unique configuration of each enzyme allows the connection with the correct substrate, among the different molecules within the cells. Therefore, for each type of chemical reaction that occurs in a cell, there is a certain enzyme that catalyzes this reaction (AGRIOS, 2005; TORTORA, 2012). For example, proteinases, cellulases, and lipases degrade proteins, celluloses, and lipids, respectively.

Soilborne phytopathogenic fungi cause losses in many crops, sometimes turning unprofitable vast agricultural areas (AMBRÓSIO et al., 2009). During the infection process, a phytopathogen needs to penetrate and colonize the host plant tissues, removing the nutrients necessary for plant activity and survival, as well as neutralize the plant defense reactions. To that end, the pathogen uses substances such as enzymes, toxins, and hormones (PASCHOLATI, 2011). According to BATEMAN; BASHAM (1976), many fungi produce extracellular enzymes of importance for the degradation and transport of nutrients into the cell and for the process of pathogenesis. Phytopathogenic fungi can produce highly specific enzymes to degrade cellular constituents, whether they are within plant tissues (in vivo) or under a specific culture medium (in vitro) (RIOU et al., 1992). OLIVEIRA SILVA et al. (2006) report that extracellular enzymes might indicate the pathogenic characteristics of fungi. Extracellular enzymes play an important role in the fungus pathogenesis in plants, but they are also an important tool in manufacturing many industrial products. They are used in the food, chemical, textile, and pharmaceutical industries (ALKORTA et al., 1998).

Most mycologists use a limited range of culture media from which potato-dextrose-agar (PDA) is the best known and most widely used to isolate and grow fungus (GRIFFITH et al., 2007). According to RUEGGER; TAUK-TORNISIETO (2004), cellulase production depends on the type of substrate used, and their comparison has been hampered by the distinct methods in the studies. Furthermore, there are different criteria to evaluate and report data about enzymes (BASTOS, 2005; BOCCHESE et al., 2003; CUZZI et al., 2011; KRISHNAN et al., 2011).

Few attempts have been carried out to compare culture media (in vitro) with respect to their efficiency in detecting extracellular enzymes produced by fungi. Thus, the objective of this study was to compare specific culture media commonly reported in the literature (normal) with the PDA medium combined with a specific compound that induces enzyme production, regarding their efficiency in detecting extracellular enzymes produced by three different soilborne phytopathogenic fungi, employing different criteria to evaluate and report enzyme data.

\section{MATERIAL AND METHODS}

\section{Isolates, inoculum production, culture media, and enzyme detection}

Three soilborne phytopathogenic fungi provided by the Fungal Culture Collection CAPSA (Plant Pathology)/APTA were used, Sclerotium rolfsii from Ajuga reptans (IBSR01), Rhizoctonia solani AG-4 HGI from chrysanthemum (IBRS01) and Fusarium solani $\mathrm{f}$. sp. passiflorae from yellow passion fruit (MMBF 08/14).

The inoculum of each fungus was produced on PDA medium inside Petri dishes (90 $\mathrm{mm}$ diameter) kept in a growth chamber at $23^{\circ} \mathrm{C}$ in the dark for eight days. After preparing the media for enzyme detection, a plug of PDA medium $(5 \mathrm{~mm})$ containing structures of each fungus was transferred to the center of each dish or test tube with enzyme media.

The specific media reported in the literature (normal) to produce and detect enzymes in the medium are described as follows.

Amylase was detected in a medium $\left(6 \mathrm{~g}\right.$ of $\mathrm{NaNO}_{3} ; 1.5$ $\mathrm{g}$ of $\mathrm{KH}_{2} \mathrm{PO}_{4} ; 0.5 \mathrm{~g}$ of KCl; $0.5 \mathrm{~g}$ of $\mathrm{MgSO}_{4} .7 \mathrm{H}_{2} \mathrm{O} ; 0.01 \mathrm{~g}$ of $\mathrm{FeSO}_{4} ; 0.01 \mathrm{~g}$ of $\mathrm{ZnSO}_{4} ; 15 \mathrm{~g}$ of agar; $1,000 \mathrm{~mL}$ of distilled $\mathrm{H}_{2} \mathrm{O}$ ) containing $1 \%$ soluble starch (specific compound), with $\mathrm{pH}$ 6.8. The dishes with amylase medium plus fungi were incubated in a growth chamber at $23^{\circ} \mathrm{C}$ for 5 days, under dark conditions. Amylolytic activity (halo) of each fungus was observed by adding $5 \mathrm{~mL}$ of Lugol's solution ( $1 \mathrm{~g}$ of iodine, $2 \mathrm{~g}$ of potassium iodide in $300 \mathrm{~mL}$ of distilled water) to the medium and waiting $10 \mathrm{~min}$ for the reaction. Amylase activity was detected by a light halo around the colony, in contrast with a purple background (PEREIRA, 2009).

Carboxymethylcellulase was observed in a medium $\left(0.5 \mathrm{~g} \mathrm{NaNO}_{3} ; 1.0 \mathrm{~g} \mathrm{~K}_{2} \mathrm{HPO}_{4} ; 0.5 \mathrm{~g} \mathrm{MgSO}_{4} .7 \mathrm{H}_{2} \mathrm{O} ; 0.001 \mathrm{~g}\right.$ $\mathrm{FeSO}_{4} \cdot 7 \mathrm{H}_{2} \mathrm{O} ; 1.0 \mathrm{~g}$ of yeast extract; $16 \mathrm{~g}$ agar; and $1,000 \mathrm{~mL}$ of distilled $\mathrm{H}_{2} \mathrm{O}$ ) supplemented with $1 \%$ of carboxymethylcellulose (specific compound). The dishes with carboxymethylcellulase medium plus fungi were incubated in a growth chamber at $23^{\circ} \mathrm{C}$ in the dark for 5 days. Carboxymethylcellulase activity was detected by the presence of clear zones (transparent) around the fungus colony, after applying $5 \mathrm{~mL}$ of Lugol's solution to the colony and waiting $5 \mathrm{~min}$ for the reaction. Next, the colony was washed with saline solution $(6 \mathrm{~g} \mathrm{NaCl}$ in $100 \mathrm{~mL}$ of distilled water) (KASANA et al., 2008).

Lipase was observed in a medium (SIERRA, 1957) $(10 \mathrm{~g}$ peptone; $5 \mathrm{~g} \mathrm{NaCl} ; 0.1 \mathrm{~g} \mathrm{CaCl}_{2} ; 17 \mathrm{~g}$ of agar; $1,000 \mathrm{~mL}$ of distilled $\mathrm{H}_{2} \mathrm{O}$ ) supplemented with Tween 20 (specific compound) $(1 \mathrm{~mL} / 100 \mathrm{~mL}$ medium $)$ and $0.001 \%$ of Rhodamine $\mathrm{B}$, with the $\mathrm{pH}$ adjusted to 6.0 (BASTOS, 2005). The dishes with lipase medium plus fungi were incubated in a growth chamber at $23^{\circ} \mathrm{C}$ in the dark for 5 days. Lipolytic activity was identified by the formation of calcium crystals or a clear halo of this precipitate around the fungus colony after 
maintaining the dishes cooled to $4^{\circ} \mathrm{C}$ for 96 hours. Tween is a synthetic fat with a sorbitol chain (sugar alcohol with five carbon instead of glycerol) esterified with many fatty acids. The lipase enzyme hydrolyzes the ester linkage between the sorbitol carbon and the fatty acid carbonyl carbon to form sorbitol and free fatty acid. The $\mathrm{pH}$ changes, and the calcium connects to free fatty acids to produce a white precipitate flocculent suspended in the medium, the calcium crystals (TRIGIANO et al., 2010).

The activity of phenol-oxidases (laccase) was detected in the medium containing $20 \mathrm{~g}$ of agar supplemented with $0.5 \%(\mathrm{w} / \mathrm{v})$ of gallic acid (specific compound), $15 \mathrm{~g}$ of malt extract, and $1 \mathrm{~g}$ of peptone in $1,000 \mathrm{~mL}$ of distilled $\mathrm{H}_{2} \mathrm{O}$. The gallic acid was homogenized in $50 \mathrm{~mL}$ of distilled water and autoclaved at $120^{\circ} \mathrm{C}, 1 \mathrm{~atm}$, during 10 minutes. The other reagents were solubilized $(\mathrm{pH} 7.0)$ and autoclaved $\left(120^{\circ} \mathrm{C}\right.$, $1 \mathrm{~atm}, 20$ minutes). The dishes with laccase medium plus fungi were incubated in a growth chamber at $23^{\circ} \mathrm{C}$ in the dark for 5 days. Laccase activity was detected in the fungus colony that produced a dark brown halo (Bavendamm reaction) (CONCEIÇÃO et al., 2005). According to TRIGIANO et al. (2010), "polyphenol oxidase oxidizes adjacent hydroxyl groups in gallic acid and creates quinones, which are unstable and spontaneously polymerize to form pigmented products."

The PDA medium showed catalase activity. After incubating the fungus on catalase medium plus fungi in a growth chamber at $23^{\circ} \mathrm{C}$ in the dark for 5 days, enzyme production was detected with the addition of hydrogen peroxide solution (specific compound) at 3\% (3 drops with reaction time of 5 minutes) over the fungal culture, according to the method modified from SHIN; KIM (1998). Catalase activity was observed by the formation of bubbles over or around the colony of the fungus.

Proteolytic activity (or proteases) was identified by the production of the gelatinase enzyme. Gelatinase was detected in test tubes containing a medium composed of $3.0 \mathrm{~g}$ of meat extract, $5.0 \mathrm{~g}$ of peptone, and $120 \mathrm{~g}$ of gelatin (specific compound) in $1,000 \mathrm{~mL}$ of distilled $\mathrm{H}_{2} \mathrm{O}$. After incubating the fungus on gelatinase medium plus fungi in a growth chamber at $23^{\circ} \mathrm{C}$ in the dark for 5 days, the tubes were placed inside the refrigerator $\left(4^{\circ} \mathrm{C}\right)$ for one hour. Gelatinase activity was detected when the medium inside the tubes under refrigeration did not return to a solid state (VERMELHO et al., 2006).

Other means to identify enzyme production consisted of using PDA medium (Difco ${ }^{\text {TM }}$ Potato-Dextrose-Agar) with the addition of a specific compound for each enzyme detection. According to GAMS et al. (1998), the PDA medium contains $1.5 \%$ of agar, $2 \%$ of glucose, nitrogen, phosphorus, vitamins, and micronutrients derived from a filtered extract of raw macerated potatoes ( $57.5 \mathrm{~g}$ of potatoes to $1 \mathrm{~L}$ of medium). The option to use the PDA medium plus specific compound instead of normal media was due to the fact that any laboratory could prepare the medium after acquiring the specific compound. In addition, several genera of fungi may grow on this medium. Producing normal media requires the purchase of many products.

All media were autoclaved at $120^{\circ} \mathrm{C}, 1 \mathrm{~atm}$, for 20 minutes, except some compounds, such as gallic acid and Tween 20, which were autoclaved separately at $120^{\circ} \mathrm{C}, 1 \mathrm{~atm}$, for $10 \mathrm{~min}$ utes, cooled, and added to the media.

The fungi $R$. solani and S. rolfsii were incubated in a growth chamber at $23^{\circ} \mathrm{C}$ in the dark, for 3 days, due to their fast growth.

\section{Experimental design and evaluation criteria}

The experimental design was completely randomized in a factorial scheme (media, isolates, and enzymes), with six replications, each one consisting of a plastic Petri dish $(90 \mathrm{~mm}$ diameter) or glass test tube containing the medium and the fungus isolate. Control treatmets were all the media not colonized by the fungi isolate.

The enzymes were detected by five different criteria, described as follows.

Criterion 1 - Calculation of the circular crown for amylase, carboxymethylcellulase, lipase, and laccase. Gelatinase and catalase had their intensity (symbols) measured and transformed into a note scale. We determined the area of the circular crown using a formula by GIECK (w/year) and measured the symbols with a methodology by BASTOS (2005). Area of the circular crown $=\pi(\mathrm{d}+\mathrm{b}) \mathrm{b}$, in which $\mathrm{b}=(\mathrm{D}-\mathrm{d}) / 2 . \pi=\mathrm{pi}$; $\mathrm{D}=\varnothing$ enzyme halo $+\varnothing$ fungus colony; $\mathrm{d}=\varnothing$ fungus colony; and $\mathrm{b}=\varnothing$ enzyme halo. According to BASTOS (2005), the production of gelatinase enzymes (protease) and catalase was estimated by symbols, based on the intensity of liquefaction of the medium (gelatinase) or the formation of bubbles and their size (catalase): +++ (intense); ++ (moderate); + (weak); and - (absent). The symbols were then replaced by the note scale: $+++=4.0 ;++=3.0 ;+=2.0$; and $-=1.0$.

Criterion 2 - Calculation of the enzymatic index (EI). BOCCHESE et al. (2003) described this criterion, evaluating the enzymes by measuring two orthogonal diameters of the colony and the corresponding halo. The activity was estimated by the EI that expressed the relationship between the average diameter of the colony and the average diameter of the halo.

Criterion 3 - Calculation of the Pz index. HANKIN; ANAGNOSTAKIS (1975) defined this criterion as the relation between the diameter of the colony and the diameter of the colony plus halo. Activity is considered negative when $\mathrm{Pz}=1.0$, positive when $0.64 \leq \mathrm{Pz}<1.0$; and strongly positive when $\mathrm{Pz}<0.64$.

Criterion 4 - Calculation of the RA index. KRISHNAN et al. (2011) described this criterion using the formula $\mathrm{RA}=$ (halo diameter-colony diameter)/halo diameter. According to authors cited by KRISHNAN et al. (2011) and modifications, 
if RA > 1.0, enzymatic activity (SEA) is significant, and if RA $<1.0$, enzymatic activity is not significant (NSEA).

Criterion 5-Using a note scale. BASTOS (2005) defined this criterion. The production of amylase, carboxymethylcellulase, lipase, and laccase was detected by measuring the diameter of the halo formed around the colonies, represented by the note scale: 0 , no enzyme production; 1 , halo with diameter between $1-5 \mathrm{~mm}$; , diameter between $5-10 \mathrm{~mm}$; 3 , diameter between $10-20 \mathrm{~mm}$; 4, diameter between 20 $30 \mathrm{~mm}$; and 5, diameter exceeding $30 \mathrm{~mm}$. For catalase and gelatinase, we used symbols to estimate their production: +++ intense; ++ moderate; + weak; e - absent.

\section{Statistical analysis}

We applied the non-parametric analysis of variance to the two or three-factor models composing the groups (Kruskal-Wallis test), complemented with Dunn's multiple comparison test and the Bonferroni correction (ZAR, 2009), considering 5\% significance level.

\section{RESULTS}

For the F. solani fungus, both normal and PDA media showed similar results to catalase and carboxymethylcellulase enzymes. Normal media were superior to PDA when the gelatinase and lipase enzymes were detected. In this case, the PDA medium plus specific compound was not suitable to identify the production of gelatinase and lipase enzymes. Amylase and laccase were not detected for $F$. solani in the tested media (Table 1).

For $S$. rolfsii, data from normal and PDA media were similar with respect to catalase and laccase enzyme production. S. rolfsii did not produce amylase, carboxymethylcellulase, lipase, and gelatinase in the media tested (Table 1).

As for $R$. solani, the results from normal and PDA media were the same regarding catalase, gelatinase, and laccase enzyme production. Lipase was not detected in the PDA medium. Amylase and carboxymethylcellulase were not produced in the tested media (Table 1).

Table 1. Extracellular enzymes produced by Fusarium solani f. sp. passiflorae, Sclerotium rolfsii, and Rhizoctonia solani AG-4 HGI grown on two media. The media were kept in a growth chamber at $23^{\circ} \mathrm{C}$ in the dark for 3 to 5 days.

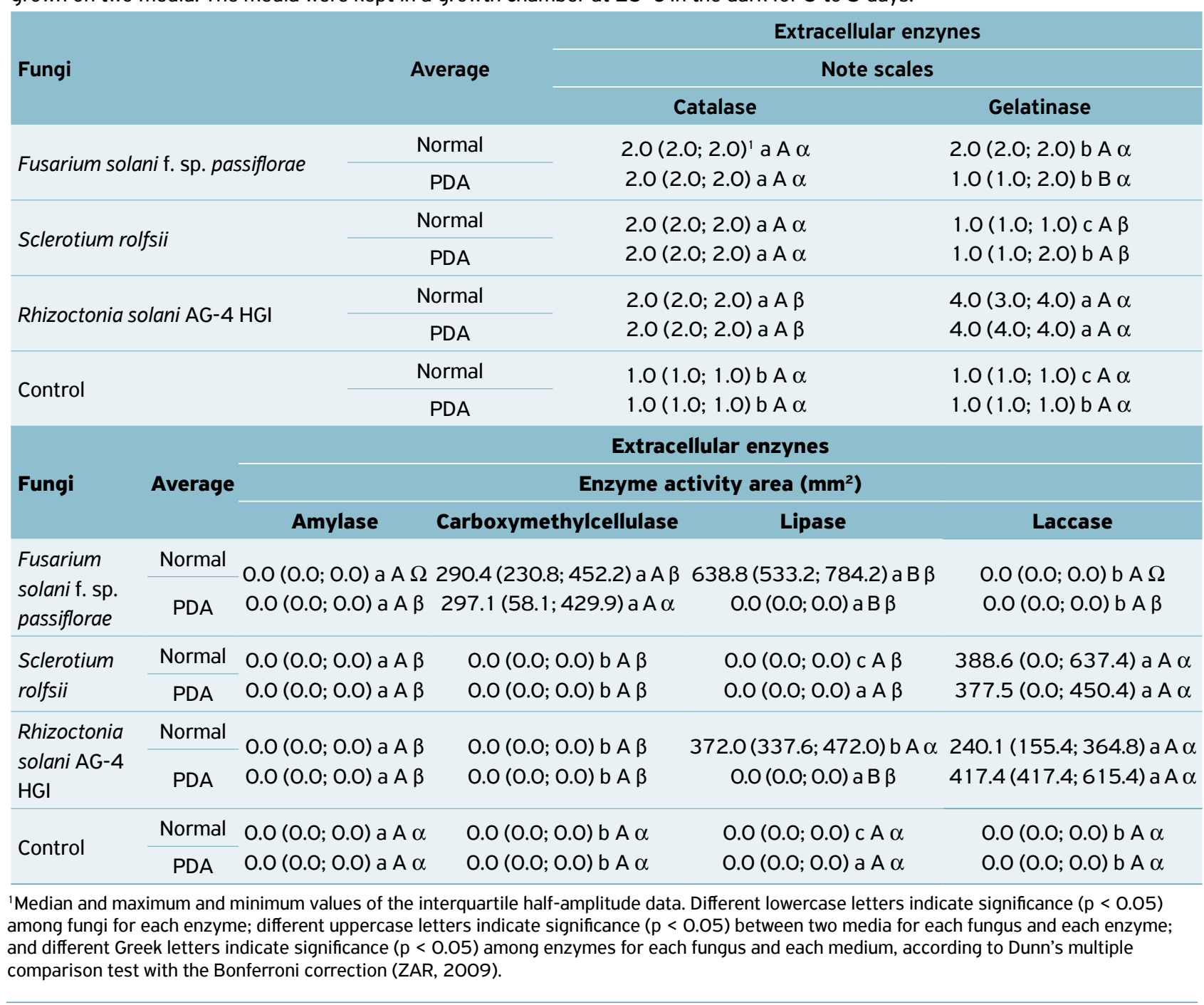


Due to the larger amount of enzymes produced in the normal media and the easier observation of enzyme halos (Table 1), these media were superior to the PDA medium plus compound.

Evaluating the fungi and the catalase and gelatinase enzymes, criteria 1 and 5 were similar concerning the production of these enzymes. For criterion 1, we applied statistical analysis to the data, while for criterion 5, statistical analysis was not possible. The difference in fungal production compared to the control treatment, except for the gelatinase enzyme in the $S$. rolfsii fungus, indicates that enzyme production resulted from the fungus, not the culture medium.

According to criterion 1, lipase was the enzyme with the largest production area for the fungi $F$. solani and $R$. solani. The enzyme most produced by $S$. rolfsii was laccase. No amylase enzyme production area was detected for any fungi (Table 2 ).

Considering only the fungus $R$. solani, lipase and laccase exhibited the same enzymatic activity for criteria 2, 3, 4, and 5. Criterion 1 showed differences in the activity of these enzymes (Table 2).

Assessing only the fungus $F$. solani, the lipase and carboxymethylcellulase enzymes demonstrated similar activities for criteria 3 and 4, differing from criteria 1,2, and 5, in which lipase and carboxymethylcellulase enzymes showed distinct activities (Table 2).

For criterion 4, the enzymes amylase, lipase, carboxymethylcellulase, and laccase had no significant activity for any fungus. This criterion contrasts with the other criteria (Table 2).

Criteria 2, 3, and 4 do not include methodologies to analyze the production of the enzymes catalase and gelatinase (Table 2).

Criteria 1 and 5 showed proportional production intensity in the enzymes amylase, carboxymethylcellulase, lipase, and laccase when the fungus F. solani was analyzed. These same enzymes showed proportional production when criteria 1 and 3 analyzed the fungus $S$. rolfsii. For $R$. solani and all enzymes, criterion 5 had similar proportionality to criteria 2 and 3 , whereas criterion 1 was totally different from the others (Table 2).

\section{DISCUSSION}

The three phytopathogens cause important diseases known as root and collar rot and can attack plants from their early to adult stages, compromising the development of tissues and the absorption of water and mineral elements. We found variability among the fungi regarding the enzyme production. F. solani produced catalase, gelatinase, carboxymethylcellulase, and lipase; $S$. rolfsii, only laccase and catalase; and $R$. solani, catalase, gelatinase, lipase, and laccase. The phytopathogens did not produce amylase. Evaluating the enzyme production by $F$. solani isolates from passion fruit, BUENO et al. (2009) detected the production of lipase, cellulase, catalase, and gelatinase. The amount of the first two enzymes produced by the fungi varied. Although $S$. rolfsii is recognized for its excellent ability to produce cellulolytic and hemicellulolytic enzymes (SACHSLEHNER et al., 1998), the present study did not detect carboxymethylcellulase production. $R$. solani is known to secrete cellulolytic and pectinolytic enzymes responsible for the colonization and collapse of plant tissues. Laccase, cellulase, pectinase, and xylanase enzymes were detected for $R$. solani from lupine, highlighting the important role of laccase in pathogenicity (BORA et al., 2005).

Catalase could be responsible for the fungi capacity to suppress plant defense (DIXON et al., 1994). Lignocellulosic material

Table 2. Extracellular enzymes produced by the fungi Fusarium solani f. sp. passiflorae, Sclerotium rolfsii, and Rhizoctonia solani AG-4 HGI grown on normal media and evaluated by different criteria.

\begin{tabular}{|c|c|c|c|c|c|c|c|c|c|c|}
\hline \multirow{3}{*}{ Enzymes } & F. solani & Control & F. solani & Control & F. solani & Control & F. solani & Control & F. solani & Control \\
\hline & \multicolumn{10}{|c|}{ Criteria to evaluate extracellular enzymes } \\
\hline & \multicolumn{2}{|c|}{$\begin{array}{c}1 \text { - Note scale } \\
\text { and Area }\left(\mathrm{mm}^{2}\right)\end{array}$} & \multicolumn{2}{|c|}{2 - El } & \multicolumn{2}{|c|}{$3-P z$} & \multicolumn{2}{|c|}{4 - RA } & \multicolumn{2}{|c|}{$\begin{array}{l}5 \text { - Symbols and Halo } \\
(\mathrm{mm})+\text { Note scale }\end{array}$} \\
\hline Catalase & $\begin{array}{c}2.0^{2} \text { a B } \\
(2.0 ; 2.0)\end{array}$ & $\begin{array}{c}1.0 \text { a A } \\
(1.0 ; 1.0)\end{array}$ & \multicolumn{2}{|l|}{ * } & \multicolumn{2}{|c|}{ * } & \multicolumn{2}{|c|}{ * } & + & - \\
\hline Gelatinase & $\begin{array}{c}2.0 \text { a B } \\
(2.0 ; 2.0)\end{array}$ & $\begin{array}{c}1.0 \text { a A } \\
(1.0 ; 1.0)\end{array}$ & \multicolumn{2}{|l|}{ * } & \multicolumn{2}{|c|}{ * } & \multicolumn{2}{|c|}{ * } & + & - \\
\hline Amylase & $\begin{array}{c}0.0 \text { a A } \\
(0.0 ; 0.0)\end{array}$ & $\begin{array}{c}0.0 \text { a A } \\
(0.0 ; 0.0)\end{array}$ & $\begin{array}{c}1.0 \text { b A } \\
(1.0 ; 1.0)\end{array}$ & $\begin{array}{c}1.0 \text { a A } \\
(1.0 ; 1.0)\end{array}$ & $1.0(\mathrm{~N})$ & $1.0(\mathrm{~N})$ & NSEA & NSEA & $0(0)$ & $0(0)$ \\
\hline CMCase $^{1}$ & $\begin{array}{c}290.4 \text { b B } \\
(230.8 ; 452.2)\end{array}$ & $\begin{array}{c}0.0 \text { a A } \\
(0.0 ; 0.0)\end{array}$ & $\begin{array}{c}0.92 \text { b A } \\
(0.88 ; 0.94)\end{array}$ & $\begin{array}{c}1.0 \text { a A } \\
(1.0 ; 1.0)\end{array}$ & $0.92(P)$ & $1.0(\mathrm{~N})$ & NSEA & NSEA & $4(1)$ & $\mathrm{O}(0)$ \\
\hline Lipase & $\begin{array}{c}638.8 \text { с B } \\
(533.2 ; 784.2)\end{array}$ & $\begin{array}{c}0.0 \text { a A } \\
(0.0 ; 0.0)\end{array}$ & $\begin{array}{c}0.87 \text { a A } \\
(0.85 ; 0.89)\end{array}$ & $\begin{array}{c}1.0 \text { a B } \\
(1.0 ; 1.0)\end{array}$ & $0.87(P)$ & $1.0(\mathrm{~N})$ & NSEA & NSEA & $8(2)$ & $0(0)$ \\
\hline Laccase & $\begin{array}{c}0.0 \text { a A } \\
(0.0 ; 0.0)\end{array}$ & $\begin{array}{c}0.0 \text { a A } \\
(0.0 ; 0.0)\end{array}$ & $\begin{array}{c}1.0 \text { b A } \\
(1.0 ; 1.0)\end{array}$ & $\begin{array}{c}1.0 \text { a A } \\
(1.0 ; 1.0)\end{array}$ & $1.00(\mathrm{~N})$ & $1.0(\mathrm{~N})$ & NSEA & NSEA & $\mathrm{O}(0)$ & $\mathrm{O}(0)$ \\
\hline
\end{tabular}


Table 2. Continuation.

\begin{tabular}{|c|c|c|c|c|c|c|c|c|c|c|}
\hline \multirow{3}{*}{ Enzymes } & S. rolfsii & Control & S. rolfsii & Control & S. rolfsii & Control & S. rolfsii & Control & S. rolfsii & Control \\
\hline & \multicolumn{10}{|c|}{ Criteria to evaluate extracellular enzymes } \\
\hline & \multicolumn{2}{|c|}{$\begin{array}{c}1 \text { - Note scale } \\
\text { and Area }\left(\mathrm{mm}^{2}\right)\end{array}$} & \multicolumn{2}{|c|}{$2-\mathrm{EI}$} & \multicolumn{2}{|c|}{$3-P z$} & \multicolumn{2}{|c|}{4 - RA } & \multicolumn{2}{|c|}{$\begin{array}{c}5 \text { - Symbols and Halo } \\
(\mathrm{mm})+\text { Note scale }\end{array}$} \\
\hline Catalase & $\begin{array}{c}2.0 \text { a B } \\
(2.0 ; 2.0)\end{array}$ & $\begin{array}{c}1.0 \text { a A } \\
(1.0 ; 1.0)\end{array}$ & \multicolumn{2}{|l|}{ * } & \multicolumn{2}{|c|}{ * } & \multicolumn{2}{|c|}{ * } & + & - \\
\hline Gelatinase & $\begin{array}{c}1.0 \text { b A } \\
(1.0 ; 1.0)\end{array}$ & $\begin{array}{c}1.0 \text { a A } \\
(1.0 ; 1.0)\end{array}$ & \multicolumn{2}{|l|}{ * } & \multicolumn{2}{|c|}{ * } & \multicolumn{2}{|c|}{ * } & - & - \\
\hline Amylase & $\begin{array}{c}0.0 \text { a A } \\
(0.0 ; 0.0)\end{array}$ & $\begin{array}{c}0.0 \text { a A } \\
(0.0 ; 0.0)\end{array}$ & $\begin{array}{c}1.0 \text { a A } \\
(1.0 ; 1.0)\end{array}$ & $\begin{array}{c}1.0 \text { a A } \\
(1.0 ; 1.0)\end{array}$ & $1.0(\mathrm{~N})$ & $1.0(\mathrm{~N})$ & NSEA & NSEA & $\mathrm{O}(0)$ & $\mathrm{O}(0)$ \\
\hline CMCase $^{1}$ & $\begin{array}{c}0.0 \text { a A } \\
(0.0 ; 0.0)\end{array}$ & $\begin{array}{c}0.0 \text { a A } \\
(0.0 ; 0.0)\end{array}$ & $\begin{array}{c}1.0 \text { a A } \\
(1.0 ; 1.0)\end{array}$ & $\begin{array}{c}1.0 \text { a A } \\
(1.0 ; 1.0)\end{array}$ & $1.0(\mathrm{~N})$ & $1.0(\mathrm{~N})$ & NSEA & NSEA & $\mathrm{O}(0)$ & $\mathrm{O}(0)$ \\
\hline Lipase & $\begin{array}{c}0.0 \text { a A } \\
(0.0 ; 0.0)\end{array}$ & $\begin{array}{c}0.0 \text { a A } \\
(0.0 ; 0.0)\end{array}$ & $\begin{array}{c}1.0 \text { a A } \\
(1.0 ; 1.0)\end{array}$ & $\begin{array}{c}1.0 \text { a A } \\
(1.0 ; 1.0)\end{array}$ & $1.0(\mathrm{~N})$ & $1.0(\mathrm{~N})$ & NSEA & NSEA & $\mathrm{O}(0)$ & $\mathrm{O}(0)$ \\
\hline Laccase & $\begin{array}{c}388.6 \text { b A } \\
(0.0 ; 637.4)\end{array}$ & $\begin{array}{c}0.0 \text { a B } \\
(0.0 ; 0.0)\end{array}$ & $\begin{array}{c}0.92 \text { a } A \\
(0.89 ; 1.0)\end{array}$ & $\begin{array}{c}1.0 \text { a A } \\
(1.0 ; 1.0)\end{array}$ & $0.93(P)$ & $1.0(\mathrm{~N})$ & NSEA & NSEA & $4(1)$ & $\mathrm{O}(0)$ \\
\hline \multirow{3}{*}{ Enzymes } & R. solani & Control & R. solani & Control & R. solani & Control & R. solani & Control & R. solani & Control \\
\hline & \multicolumn{10}{|c|}{ Criteria to evaluate extracellular enzymes } \\
\hline & \multicolumn{2}{|c|}{$\begin{array}{c}1 \text { - Note scale } \\
\text { and Area }\left(\mathrm{mm}^{2}\right)\end{array}$} & \multicolumn{2}{|c|}{2 - EI } & \multicolumn{2}{|c|}{$3-\mathrm{Pz}$} & \multicolumn{2}{|c|}{4 - RA } & \multicolumn{2}{|c|}{$\begin{array}{l}5 \text { - Symbols and Halo } \\
(\mathrm{mm})+\text { Note scale }\end{array}$} \\
\hline Catalase & $\begin{array}{c}2.0 \text { b B } \\
(2.0 ; 2.0)\end{array}$ & $\begin{array}{c}1.0 \text { a A } \\
(1.0 ; 1.0)\end{array}$ & \multicolumn{2}{|l|}{ * } & \multicolumn{2}{|c|}{ * } & \multicolumn{2}{|c|}{ * } & + & - \\
\hline Gelatinase & $\begin{array}{c}4.0 \text { a B } \\
(3.0 ; 4.0)\end{array}$ & $\begin{array}{c}1.0 \text { a A } \\
(1.0 ; 1.0)\end{array}$ & \multicolumn{2}{|l|}{ * } & \multicolumn{2}{|c|}{ * } & \multicolumn{2}{|c|}{ * } & +++ & - \\
\hline Amylase & $\begin{array}{c}0.0 \text { a A } \\
(0.0 ; 0.0)\end{array}$ & $\begin{array}{c}0.0 \text { a A } \\
(0.0 ; 0.0)\end{array}$ & $\begin{array}{c}1.0 \text { b A } \\
(1.0 ; 1.0)\end{array}$ & $\begin{array}{c}1.0 \text { a A } \\
(1.0 ; 1.0)\end{array}$ & $1.0(\mathrm{~N})$ & $1.0(\mathrm{~N})$ & NSEA & NSEA & $\mathrm{O}(0)$ & $\mathrm{O}(0)$ \\
\hline CMCase $^{1}$ & $\begin{array}{c}0.0 \text { a A } \\
(0.0 ; 0.0)\end{array}$ & $\begin{array}{c}0.0 \text { a A } \\
(0.0 ; 0.0)\end{array}$ & $\begin{array}{c}1.0 \text { b A } \\
(1.0 ; 1.0)\end{array}$ & $\begin{array}{c}1.0 \text { a A } \\
(1.0 ; 1.0)\end{array}$ & $1.0(\mathrm{~N})$ & $1.0(\mathrm{~N})$ & NSEA & NSEA & $\mathrm{O}(0)$ & $\mathrm{O}(0)$ \\
\hline Lipase & $\begin{array}{c}372.0 \text { c A } \\
(337.6 ; 472.0)\end{array}$ & $\begin{array}{c}0.0 \text { a B } \\
(0.0 ; 0.0)\end{array}$ & $\begin{array}{c}0.89 \text { a B } \\
(0.87 ; 0.91)\end{array}$ & $\begin{array}{c}1.0 \text { a A } \\
(1.0 ; 1.0)\end{array}$ & $0.89(P)$ & $1.0(\mathrm{~N})$ & NSEA & NSEA & $5(1)$ & $\mathrm{O}(0)$ \\
\hline Laccase & $\begin{array}{c}240.1 \text { b A } \\
(155.4 ; 364.8)\end{array}$ & $\begin{array}{c}0.0 \text { a B } \\
(0.0 ; 0.0)\end{array}$ & $\begin{array}{c}0.89 \text { a B } \\
(0.83 ; 0.91)\end{array}$ & $\begin{array}{c}1.0 \text { a A } \\
(1.0 ; 1.0)\end{array}$ & $0.87(P)$ & $1.0(\mathrm{~N})$ & NSEA & NSEA & $5(1)$ & $\mathrm{O}(0)$ \\
\hline
\end{tabular}

Criterion 1 - Calculation of the circular crown area. Formula described by GIECK (without year). This formula was used to quantify the enzymes amylase, carboxymethylcellulase, lipase, and laccase. The catalase and gelatinase enzymes were quantified by symbols describing their intensity, which were later transformed into a note scale, with $1=$ absent (or $-=$ symbol: absent); $2=$ weak (or $+=$ symbol: weak); $3=$ moderate (or $++=$ symbol: moderate); $4=$ intense (or $+++=$ symbol: intense). For catalase, the intensity refers to the size of bubble formation and for gelatinase, the liquefaction or not of the medium;

Criterion 2 - Calculation of the enzymatic index (EI). Formula described by BOCCHESE et al. (2003). This index was applied to the enzymes amylase, carboxymethylcellulase, lipase, and laccase;

Criterion 3 - Calculation of the Pz index. Formula described by HANKIN; ANAGNOSTAKIS (1975).

According to the index, enzyme activity is negative $(\mathrm{N})$ when $\mathrm{Pz}=1$, positive $(\mathrm{P})$ when $0.64 \leq \mathrm{Pz}<1$, and strongly positive $(\mathrm{SP})$ when $\mathrm{Pz}<0,64$.

This index was applied to the enzymes amylase, carboxymethylcellulase, lipase, and laccase;

Criterion 4 - Calculation of the RA index. Formula and criterion described by KRISHNAN et al. (2011) and other authors. If RA > 1, enzymatic activity (SEA) is significant, and if RA < 1, enzymatic activity is not significant (NSEA). This index was applied to the enzymes amylase, carboxymethylcellulase, lipase, and laccase;

Criterion 5 - Method described by BASTOS (2005). Measurement of the diameter of the halo formed around the colonies, represented by the note scale: (0), no enzyme production; (1), halo with diameter between 1-5 mm; (2), diameter between 5-10 mm; (3), diameter between 10-20 mm; (4), diameter between $20-30 \mathrm{~mm}$; e (5), diameter higher than $30 \mathrm{~mm}$. This method was applied to the enzymes amylase, carboxymethylcellulase, lipase, and laccase. To evaluate the enzymes catalase and gelatinase, BASTOS (2005) used symbols for a subjective estimation of enzyme production, based on the intensity of the enzymes formed in the medium: +++ intense; ++ moderate; + weak; and - absent;

*The method does not contemplate enzyme evaluation; ${ }^{1}$ carboxymethylcellulase; ${ }^{2}$ median and maximum and minimum values of the interquartile half-amplitude data.

Different lowercase letters indicate significance $(p<0.05)$ among enzymes for each fungus; different uppercase letters indicate significance of the fungus $(p<0.05$ ) within the enzyme, according to Dunn's multiple comparison test with the Bonferroni correction (ZAR, 2009). 
degradation involves a series of reactions, attributing to catalases different functions in lignin degradation (ANDRADE, 2011). SHIHATA et al. (1995) reported that $F$. moniliforme, F. oxysporum, and $F$ solani isolated from pea (Pisum sativum) produced cellulase and pectinase, both in vitro and in vivo. Higher enzymatic activity was observed in infected plants compared to healthy plants. OLIVIERI et al. (2004) stated that $F$. solani f.sp. eumartii produces protease as a strategy to colonize the potato plant (Solanum tuberosum). According to BASTOS (2005), the fungus Crinipellis perniciosa probably has to use cellulose, lipids, and/or proteins as a source of energy to produce extracellular enzymes. Enzymes degrade the components present in the infected tissue of the host - the collar region of the plants providing gradually assimilable compounds for the pathogens.

Many papers report on media that produce a particular enzyme, and ways to reveal and evaluate enzyme production and disclose enzyme activity data. Standardization of methodologies would permit comparisons of results from different studies, which has not yet been proposed.

Studying soilborne phytopathogenic fungi, RUEGGER; TAUK-TORNISIELO (2004) used a synthetic medium with carboxymethylcellulose (CMC). For fungi that did not grow in this medium, they used agar with CMC. After incubation for four days at $28^{\circ} \mathrm{C}$, the colonies underwent thermal shock for 16 hours at $50^{\circ} \mathrm{C}$. Ten $\mathrm{mL}$ of Congo red dye solution was added to Tris $\mathrm{HCl} 0.1 \mathrm{M}$ buffer, $\mathrm{pH}$ 8.0. After 30 minutes, the solution was discarded, and the cultures were washed with five $\mathrm{mL}$ of $\mathrm{NaCl} 0.5 \mathrm{M}$, in the same buffer, for subsequent measurement of the diameter of the halo and the colony with a caliper. For Crinipellis perniciosa (BASTOS, 2005), a mineral salts agar medium (TUITE, 1969) supplemented with CMC was used. According to KRISHNAN et al. (2011), a basal medium called R2A agar supplemented with $0.4 \% \mathrm{w} / \mathrm{v}$ of CMC was used to detect the respective enzyme in the Antarctic soil fungi.

KRISHNAN et al. (2011) used the R2A agar basal medium supplemented with $0.01 \% \mathrm{w} / \mathrm{v}$ of trypan blue to identify amylase. The dishes were incubated at $4^{\circ} \mathrm{C}$ for 10 days. After this period, amylase activity was detected with Lugol's solution. The amylase produced by endophytic fungi isolated from Baccharis dracunculifolia D.C. (CUZZI et al., 2011) was detected in a minimum medium (MM) supplemented with soluble starch at $2 \%$ and $\mathrm{pH} 6.0$, incubated at $28^{\circ} \mathrm{C}$ for seven days. After this period, the dishes were stained with Lugol's solution. The production of amylase by Crinipellisperniciosa (BASTOS, 2005) was detected in a nutrientagar (NA) medium containing $0.2 \%$ soluble starch, as firstly described by COON et al. (1957). For Pyrenophora chaetomioides, amylase was detected in the NA medium plus $0.2 \%$ starch and $\mathrm{pH}$ 6.0. After incubation, $10 \mathrm{~mL}$ of an alcoholic solution of iodine was added, and the yellowish halo around the colony was measured (BOCCHESE et al., 2003).

Assessing lipases, CUZZI et al. (2011) reported a MM supplemented with $2 \%$ Tween 80 and $\mathrm{pH}$ 6.5, while BOCCHESE et al. (2003) used another basal medium plus 1\% Tween 20.
After incubation, the dishes were cooled to $4^{\circ} \mathrm{C}$ for 48 hours, and the halo with calcium crystals was measured.

Analyzing proteases, KRISHNAN et al. (2011) added 0.4\% w/v of skim milk powder to the R2A agar basal medium, followed by a drop of Coomassie brilliant blue solution. CUZZI et al. (2011) reported the production of protease using MM supplemented with $2 \%$ albumin, $\mathrm{pH} 6.5$, incubated at $28^{\circ} \mathrm{C}$ for seven days, while BOCCHESE et al. (2003) used NA medium with $4 \%$ gelatin and $\mathrm{pH} 6.0$, according to the method by HANKIN; ANAGNOSTAKIS (1975). After five days of incubation at $23^{\circ} \mathrm{C}$, a saturated solution of ammonium sulfate was added to accentuate the clear halo around the colony.

Laccase production was assessed for Aspergillus, Fusarium, Trichoderma, Cladosporium, and Penicillium in a PDA medium plus different concentrations of copper. A positive correlation between laccase activity and copper concentration was found (GRIFFITH et al., 2007). According to the authors, the micronutrient copper is essential for fungal growth, acting as a cofactor for oxidases and oxygenases, including laccases.

PDA is considered a rich medium (RITCHIE et al., 2009), especially in carbohydrates (FISHER et al., 1982). The proportion of nutrients in the PDA medium allows good growth, sporulation, and also mycelial pigmentation for a wide range of fungi (GRIFFITH et al., 2007). However, the fact that the PDA medium is richer in nutrient than the normal media (basal and poor medium) used in the present study may be due to the low or absent enzymatic production of fungal pathogens in the PDA medium. In addition, HERNÁNDEZ; HOBBIE (2010) stated that the composition of the medium could significantly affect microbial enzymatic activity. Nonetheless, there are substances in the medium that alter enzymatic activity through the process of retroinhibition, in which the end product of the enzymatic activity inhibits the action of the enzyme itself (NELSON; COX, 2011).

The literature reports different methods to produce and assess enzyme (HANKIN; ANAGNOSTAKIS, 1975; BOCCHESE et al., 2003; BASTOS, 2005; CUZZI et al., 2011). For example, the basal medium used to detect the carboxymethylcellulase enzyme in the present study is different from that described by KRISHNAN etal. (2011) and RUEGGER;TAUK-TORNISIELO (2004). In the current study, the sequence and type of dyes used to show and highlight the resulting halo were modified and adapted from studies conducted by RUEGGER; TAUK-TORNISIELO (2004); and KRISHNAN et al. (2011). The method to assess and report the amount of carboxymethylcellulase enzyme was different from the one cited by KRISHNAN et al. (2011) and RUEGGER; TAUK-TORNISIELO (2004).

Amylase detection in the present study differed from that described by KRISHNAN et al. (2011) but was almost similar to those reported by CUZZI et al. (2011), BASTOS (2005), and BOCCHESE et al. (2003). The dye and halo measurements of the enzyme were similar to those described by CUZZI et al. (2011), but the data report was different in the present work. 
In the current study, the methodology to detect lipase production was similar to that described by BASTOS (2005) and BOCCHESE et al. (2003), differing only with respect to the presence of rhodamine and incubation of the plates at $4^{\circ} \mathrm{C}$ for 96 hours. The method of evaluation was similar to that determined by BASTOS (2005), but both BASTOS (2005) and BOCCHESE et al. (2003) reported enzyme activity differently.

BASTOS (2005) method to assess laccase was similar to that of the present study, differing only with respect to data report.

The method to evaluate catalase and gelatinase was analogous to the one by BASTOS (2005), i.e., using symbols. In the present work, however, the symbols described different intensities in the medium, such as bubble size (catalase) and liquefaction of the medium (gelatinase), besides the fact that the symbols were later transformed into notes to facilitate statistical data analysis.

The present study is not definitive in detecting extracellular enzymes produced in vitro by fungi (RIOU et al., 1992), as well as quantifying them, but gives a preliminary idea of which enzyme should be further investigated.

Currently, there is no consensus regarding which method to use to detect enzymes, as well as how to evaluate and report activity data of enzymes produced by phytopathogenic fungi. Based on the results of the present study, we suggest standardizing the composition of the specific media (normal) to produce enzymes and the methodology to detect their produced halos. We also propose adopting criterion 1 as the standard procedure to calculate the area $\left(\mathrm{mm}^{2}\right)$ of the enzymes amylase, carboxymethylcellulase, lipase, and laccase, in addition to using the scale of notes to quantify catalase and gelatinase. These criteria had the best results when showing the smallest and greatest differences in enzyme production by fungi, as well as the production of each fungus compared to the control treatment. Thus, in the future, it may be possible to compare studies on enzyme data among fungi.

\section{ACKNOWLEDGMENTS}

The authors would like to thank the Coordenação de Aperfeiçoamento de Pessoal de Nível Superior - Brazil (CAPES) for the partial financial support received - Finance Code 001.

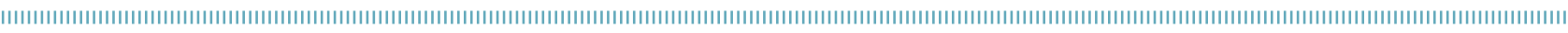
REFERENCES

AGRIOS, G.N. Plant Pathology. Burlington: Academic Press, 2005. 922p.

ALKORTA, I.; GARBISU, C.; LLAMA, M. J.; SERRA, J.L. Industrial applications of pectic enzymes: a review. Process Biochemistry, London, v.33, n.1, p.21-28, 1998. https://doi.org/10.1016/ S0032-9592(97)00046-0

AMBRÓSIO, M.M.Q.; BUENO, C.J.; PADOVANI, C.R.; SOUZA, N.L. Sobrevivência de fungos fitopatogênicos habitantes do solo, em microcosmo, simulando solarização com prévia incorporação de materiais orgânicos. Summa Phytopathologica, Botucatu, v.35, n.1, p.2025, 2009.https://doi.org/10.1590/SO100-54052009000100003

ANDRADE, A.L.C. Aspectos do crescimento e influência de parâmetros físicos na atividade da lacase do fungo amazônicoTrametes lactinea. 2011. 116p. Dissertação (Mestrado em Biotecnologia e Recursos Naturais da Amazônia) - Universidade do Estado do Amazonas, Manaus, 2011 . Available from: <http:// www.pos.uea.edu.br/data/area/titulado/download/27-1.pdf >. Accessed on: May 032017.

BASTOS C.N. Produção de enzimas extracelulares por Crinipellis perniciosa. Fitopatologia Brasileira, Brasília, v.30, n.3, p.286-288, 2005. http://doi.org/10.1590/SO100-41582005000300011

BATEMAN, D.F.; BASHAM, H.G. Degradation of plant-cell walls and membranes by microbial enzymes. In: HEITEFUSS, R.; WILLIAMS, P.H. (Eds.). Physiological Plant Pathology. Encyclopedia of Plant Physiology (New Series). v. 4. Berlin, Heidelberg: Springer. p.316355. https://doi.org/10.1007/978-3-642-66279-9_13
BOCCHESE, C.A.C.; MARTINELLI, J.A.; MATSUMURA, A.T.S.; FEDERIZZI, L.C.; PRESTES, A.M. Virulência, atividade enzimática e padrões de isoesterases de isolados de Pyrenophora chaetomioides, agente etiológico da mancha de grãos e folhas de aveia. Fitopatologia Brasileira, Brasília, v.28, n.1, p.11-16, 2003. http://doi.org/10.1590/SO100-41582003000100002

BORA, P.; HARDY, G.E.S.J.; O’BRIEN, P.A. Laccase activity and maceration of lupin tissue by Rhizoctonia solani is inhibited by arginine. Australasian Plant Pathology, Clayton, v.34, n.4, p.591594, 2005. https://doi.org/10.1071/AP05077

BUENO, C.J.; FISCHER, I.H.; ROSA, D.D.; FURTADO, E.L. Produção de enzimas extracelulares por Fusarium solani de maracujazeiro amarelo. Tropical Plant Pathology, Lavras, v.34, n.5, p.343-346, 2009. http://dx.doi.org/10.1590/S1982-56762009000500009

CONCEIÇÃO, D.M.; DE ANGELIS, D.A.; BIDOIA, E.D.; DE ANGELIS, D.F. Fungos isolados do Rio Atibaia - SP e Refinaria de Petróleo biodegradadores de compostos fenólicos. Arquivos do Instituto Biológico, São Paulo, v.72, n.1, p.99-106, 2005.

COON, H.J.; JENNISON, M.W.; WEEK, O.B. Routine tests for the identification of bacteria. In: SOCIETY OF AMERICAN BACTERIOLOGISTS (Ed.). Manual of Microbiological Methods. New York: McGraw-Hill, 1957. p.239-262.

CUZZI, C.; LINK, S.; VILANI, A.; ONOFRE, S.B. Enzimas extracelulares produzidas por fungos endofíticos isolados de Baccharis dracuncufolia D.C. (Asteraeceae). Global Science and Technology, Singapore, v.4, n.2, p.47-57, 2011. 
DIXON, R.A.; HARRISON, M.J.; LAMB, C.J. Early events in the activation of plant defense responses. Annual Review of Phytopathology, Palo Alto, v.32, n. 1, p.479-501, 1994.

FISHER, N.L.; BURGESS, L.W.; TOUSSOUN, T.A.; NELSON, P.E. Carnation leaves as a substrate and for preserving cultures of Fusarium species. Phytopathology, Saint Paul, v.72, p. 151-153, 1982. http://dx.doi.org/10.1094/Phyto-72-151

GAMS, W.; HOEKSTRA, E.S.; APTROOT, A. CBS Course on Mycology. The Netherlands: Centraalbureau voor Schimmelcultures, AG Baarn, 1998. 165p.

GIECK, K. Manual de fórmulas técnicas. São Paulo: Hemus.

GRIFFITH, G.W.;EASTON, G.L;DETHERIDGE, A.; RODERICK, K.; EDWARDS, A.; WORGAN, H.J.; NICHOLSON, J.; PERKINS, W.T. Copper deficiency in potato dextrose agar causes reduced pigmentation in cultures of various fungi. FEMS Microbiology Letters, Amsterdam, v.276, p. 165171,2007.https://doi.org/10.1111/j.1574-6968.2007.00923.x

HANKIN L.; ANAGNOSTAKIS, S.L. The use of solid media for detection of enzyme production by fungi. Mycologia, New York, v.61, n.3, p.597-607, 1975. https://doi.org/10.2307/3758395

HERNÁNDEZ, D.L.; HOBBIE, S.E. The effects of substrate composition, quantity, and diversity on microbial activity. Plant and Soil, The Hague, v.335, n.1-2, p.397-411, 2010. https:// doi.org/10.1007/s $11104-010-0428-9$

KASANA, R.C.; SALWAN, R.; DHAR, H.; DUTT, S.; GULATI, A. A rapid and easy method for the detection of microbial cellulases on agar plates using gram's iodine. Current Microbiology, New York, v.57, n.5, p.503-507, 2008. https://doi.org/10.1007/ s00284-008-9276-8

KRISHNAN, A.; ALIAS, S.A.; WONG, C.M.V.L.; KA-LAI, P.; CONVEY, P. Extracellular hydrolase enzyme production by soil fungi from King George Island, Antarctica. Polar Biology, Berlin, v.34, p.15351542, 2011 . https://doi.org/10.1007/s00300-011-1012-3

NELSON, D.L.; COX, M. M. Princípios de Bioquímica de Lehninger 5. ed. Porto Alegre: Artmed, 2011.

OLIVEIRA SILVA, R.L.; LUZ, J.S.; SILVEIRA, E.B.; CAVALCANTE, U.M.T. Fungos endofíticos em Annona spp.: isolamento, caracterização enzimática e promoção do crescimento em mudas de pinha (Anonna squamosa L). ActaBotânica Brasilica, Porto Alegre, v.20, n.3, p.649-655, 2006. https://doi.org/10.1590/SO102-33062006000300015

OLIVIERI, F.; ZANETTI, M.E.; OLIVA, C.R.; COVARRUBIAS, A.A.; CASALONGUE, C.A. Characterization of an extracellular serine protease of Fusarium eumartii and its action on pathogenesis related proteins. European Journal of Plant Pathology, Dordrecht, v. 108, n. 1, p.63-72, 2004. https://doi.org/10.1023/A:1013920929965

PASCHOLATI, S.F. Fisiologia do parasitismo: como os patógenos atacam as plantas. In: AMORIM, L.; REZENDE, J.A.M.; BERGAMIN FILHO, A. (Ed.). Manual de fitopatologia. v. 1: Princípios e conceitos. 4. ed. São Paulo: Agronômica Ceres, 2011 . p.543-589.
PEREIRA, W.V. Caracterização e identificação molecular de espécies de Colletotrichum associadas à antracnose da goiaba no Estado de São Paulo. 2009. 80p. Dissertação (Mestrado em Ciências/Fitopatologia) - Universidade do Estado de Paulo, São Paulo, 2009. Available from: <http://www.teses.usp.br/teses/disponiveis/11/11135/ tde-26022010-082342/pt-br.php>. Accessed on: May 032017. https://doi.org/10.1 1606/D.1 1.2010.tde-26022010-082342

RIOU, C.; FREYSSINET, G.; FEVRE, M. Purification and characterization of extracellular pectinolytic enzymes produced by Sclerotinia sclerotiorum. Applied Environmental Microbiology, Washington, v.58, n.2, p.578-583, 1992.

RITCHIE, F.; BAIN, R.A.; McQUILKEN, M.P. Effects of nutrient status, temperature and $\mathrm{pH}$ on mycelial growth, sclerotial production and germination of Rhizoctonia solani from potato. Journal of Plant Pathology, Los Angeles, v.91, n.3, p.589-596, 2009.

RUEGGER, M.J.S.; TAUK-TORNISIELO, S.M. Atividade da celulase de fungos isolados do solo da Estação Ecológica de JuréiaItatins, São Paulo, Brasil. Revista Brasileira de Botânica, São Paulo, v.27, n.2, p.205-211, 2004. http://doi.org/10.1590/ S0100-84042004000200001

SACHSLEHNER, A.; NIDETZKY, B.; KULBE, K.D.; HALTRICH, $D$. Induction of Mannanase, Xylanase, and Endoglucanase Activities in Sclerotium rolfsii. Applied Environmental Microbiology, Washington, v.64, n.2, p.594-600, 1998.

SHIHATA, Z.A.; ABDOU, E.S.; GALAL, A.A. Production of pectolytic and cellulolytic enzymes by Fusarium species in diseased cowpea plants and in vitro. Assiut Journal of Agricultural Sciences, Assiut, v.26, n.4, p.339-344, 1995.

SHIN, K-SOO; KIM, C-JIN. Decolorisation of artificial dyes by peroxidase from the white-rot fungus, Pleurotus ostreatus. Biotechnology Letters, Dordrecht, v.20, n.6, p.569-572, 1998. https://doi.org/10.1023/A: 1005301812253

SIERRA, S.A. Simple method for detection of lipolytic activity of microorganisms and some observations on the influence of the contact between cells and fatty substrates. Antonie van Leeuwenhoek, Wageningen, v.23, n.1, p.15-22, 1957.

TORTORA, G.J.; FUNKE, B.R.; CASE, C.L. Microbiologia. 10. ed. Porto Alegre: Artmed, 2012. 894p.

TRIGIANO, R.N.; WINDHAM, M.T.; WINDHAM, A.S. Fitopatologia Conceitos e Exercícios de Laboratório. 2. ed. Porto Alegre: Artmed, 2010. 576p.

TUITE, J. Plant pathological methods: fungi and bacteria. Minneapolis: Burgess Publishing, 1969. 239p.

VERMELHO, A.B.; PEREIRA, A.F.; COELHO, R.R.R.; SOUTO-PADRÓN, T. Práticas de microbiologia. Rio de Janeiro: Guanabara Koogan, 2006. 239p.

ZAR, J.H. Biostatistical analysis. 5. ed. New Jersey: PrenticeHall. 2009. 994p. 